\title{
Does Ownership Structure Affect Jordanian Companies' Tendency to Practice Earnings Management?
}

\author{
Imad Zeyad Ramadan (Corresponding author) \\ Full Prof., Department of Finance, Applied Science University \\ P.O. Box 166, Amman, Jordan \\ E-mail: i_ramadan@asu.edu.jo
}

Received: August 8, 2015 Accepted: Dec. 7, 2015 Published: December 7, 2015

doi:10.5296/ajfa.v7i2.8537 URL: http://dx.doi.org/10.5296/ajfa.v7i2.8537

\begin{abstract}
The aim of this paper is to examine the effect of ownership structure on a firm's ability to practice earnings management. To achieve this goal all 77th Jordanian industrial companies listed at Amman Stock Exchange (ASE) for the period 2000-2014 were selected resulting in 1089 firm-year observations. The empirical results suggest that the earnings management practices of Jordanian industrial companies listed at ASE are influenced by the ownership structure. Precisely, the result shows that equity concentration, management ownership and institutional investor equity are associated inversely with the practices of earnings management. Our results are consistent with the Alignment of Interest Hypothesis and the Efficient Monitoring Hypothesis which suggest that large shareholders have less motivation to manipulate earnings, and can reduce the scope of managerial opportunism.
\end{abstract}

Keywords: Ownership Structure; Earnings Management; Jordan 


\section{Introduction}

Most of the firm managers seek their own benefits on the expense of the shareholders. This is known as the agency problem. In the agency problem the managers interfere and manipulate the financial statements to appear them in a way that serve their own benefits even though these statements do not coincide with the real situation. The management interference in financial disclosure process may affect the figures in the financial statements. This matter may affect the quality of the content for these statements which may negatively affect the financial decisions taken by the users of these financial statements. According to Black et al. (2000), in many situations, the overdoing and misusing of the earnings management led to the collapse of many companies as a result of the low quality of the accounting information contained in the disclosed financial statements which decreased the investor's trust in data. This decrease in the trust had negative reflections on the capital markets around the globe as well as in the Arab world.

Many studies like Lev (1988)and Shiller and Pound (1989) show that the practice of earnings management will be much harder when there is equity concentration and high percentage of institutional investor's equity because the institutional investors have larger amount of information than the individual investors and also they have more financial capabilities and motivations to control the management. Greavs and Waddock (1990), Jacobs (1991), and Potter (1992) concluded that the institutional investors practice pressure on the managers to focus on short term profits on the expense of long term profits when the evaluation of their companies depends on short term performance of their portfolios. Lang and Mc-Nichols (1998) concluded that the trading volume from the institutional investors depends on short term profit which motivates the managers to practice earnings management in order to achieve short term profits as a result of the institutional investors' pressure.

The institutional investors play a major role in the capital markets due to their financial capabilities, investments experience, and their management skills compared to the individual investors. According to that, the essence of the problem statement of this study lies in the lack of evidence about the impact of the ownership structure on the ability of the companies to practice earnings management. Thus, this study seeks to answer the following question: Is there any significant effect of the ownership structure, expressed as the percentage of institutional investor's equity, on the capability of the Jordanian industrial companies to exercise earnings management?

This study aims to investigate the effect of ownership structure on the ability of the managers to practice earnings management in the Jordanian industrial companies. Thus, this study seeks to test the hypothesis that the ability of the Jordanian industrial companies to practice earnings management is affected significantly by the ownership structure.

\section{Literature Review}

The number of studies that handled the effect of corporate governance on the Earnings Management (EM) is relatively small in literature. Beeker et al. (1998), Francis et al. (1999), and Chung et. al. (2002) are considered among the few researchers that have 
conducted pieces of research in this area. Those researchers studied the relation between the quality of auditing and accruals management and they concluded that the auditing by the six big auditors reduces the level by which the managers practice Earnings Management through manipulating discretionary accruals.

In addition, the study of Francis et al. (1999) concluded that the auditing of the six big auditors reduces the ability of the managers to manipulate the accounting accruals. Moreover, Chung et al. (2002) concluded that the increase in the percentage of the institutional investor's equity reduces the ability of the management to practice earnings management to smooth the income in order to reach the target profit. Klein (2002) suggested that the change in the independent status of the auditing committee coincides with the change in the ability of the managers to practice the earnings management. Furthermore, he concluded that an independent auditing committee is more efficient in controlling the disclosure of the financial data because the companies with high number of independent auditors have lower volume of extra ordinary accruals.

Sanjar S. et al. (2012), investigated the effect of ownership structure on earnings management for Tehran Stock Exchange. The researchers divided the firms into two groups according to the type of investors; group 1 included the institutional investors whereas group 2 involved the individual investors. The results show that the firms which have low profits before accruals practice earnings management are more than those firms with high profits before accruals. Also the study suggested that firms with high percentage of institutional investors are involved heavily in practicing earnings management.

Frooq O. and El Jai H., (2012) studied the effect of ownership structure on earnings management in Morocco. The results have showed that the institutional investors play a major role in reducing the earnings management practices because those investors have greater resources to monitor managers within the firms than individual investors. Also their study suggested that the ownership concentration has no significant effect on earnings management. This result seems to contradict with other studies.

Rajgopal, S., (1999) investigated the difference between two contradicting views about institutional owners. On one hand, the institutional owners can be fooled by earnings management practiced by the managers in generating short term profits to satisfy institutional owner's interest. On the other hand, institutional owners are sophisticated investors so they cannot be fooled by earnings management practices. The results supported the view that the institutional owners are sophisticated investors and thus suggested an inverse relation between the institutional owners and earnings management practices.

\section{Methodology}

\subsection{Data}

This study used econometric analysis utilizing unbalanced panel data regression of all $77^{\text {th }}$ Jordanian industrial companies listed at Amman Stock Exchange for the period 2000-2014 resulting in 1089 firm-year observations. The needed data were derived from the ASE. 


\section{Macrothink}

\subsection{Study variables}

\subsubsection{Dependent variable: Earnings Management}

The dependent variable in the study is the Earnings Management expressed as the discretionary accruals. The discretionary accruals can be calculated as the difference between the total accruals and the non-discretionary accruals.

Jones (1991) calculated the total accruals as the difference between the annual sales change and the change in the accounts receivables to which the gross property is added based on equation (1):

$$
C A_{\text {it }}=\alpha+\beta_{1}\left(\Delta S_{i t}-\Delta \mathrm{AR}_{\mathrm{it}}\right)+\beta_{2} \mathrm{PPE}_{\mathrm{it}}+\varepsilon_{\mathrm{it}}
$$

Where $C A_{\text {it }}$ is total accruals for company $i$ within the period $t, \alpha$ is the linear regression line constant, $\beta^{\prime s}$ are the coefficients of the linear regression line, $\Delta$ is the annual change, $\mathrm{S}$ is the annual sales, AR is the accounts receivable, PPE is the gross property that includes property, plants, and equipment's, and $\varepsilon$ is the random error.

To reduce the effect of the potential heteroscedasticity problem the equation was divide by the previous year total assets of the company. Therefore equation (1) can be rewritten as:

$$
\frac{\mathrm{CA}_{\mathrm{it}}}{\mathrm{TA}_{\mathrm{L}, t-1}}-\alpha \frac{1}{\mathrm{TA}_{1, t-1}}+\beta_{1}\left(\frac{\Delta S_{\mathrm{it}}-\Delta \mathrm{AR}_{\mathrm{it}}}{\mathrm{TA}_{\mathrm{it}-1}}\right)+\beta_{2}\left(\frac{\mathrm{PPE}_{\mathrm{it}}}{\mathrm{TA}_{1, t-1}}\right)+\varepsilon_{\mathrm{it}}
$$

Where $\mathrm{TA}_{1, t-1}$ is the total asset for company $\mathrm{i}$ at time $\mathrm{t}-1$.

To calculate the discretionary accruals equation (2) will be applied for each company of the study sample independently, and then the coefficient of the linear regression estimated by equation (2) is used to estimate the non-discretionary accruals independently for each company. The discretionary accruals will be calculated by subtracting the estimated non-discretionary accruals from the total accruals. This value can be seen as the residuals of equation (2) and thus can be mathematically calculated by equation (3) as follows:

$$
\mathrm{DCA}_{1 \mathrm{t}}=\frac{\mathrm{CA}_{1 \mathrm{t}}}{\mathrm{TA}_{1, t-1}}-\stackrel{a}{\alpha}\left(\frac{1}{\mathrm{TA}_{1, t-1}}\right)+\stackrel{a}{\beta_{1}}\left(\frac{\Delta \mathrm{S}_{1 \mathrm{t}}-\Delta \mathrm{AR}_{\mathrm{it}}}{\mathrm{TA}_{1, t-1}}\right)+{ }_{\beta_{2}}\left(\frac{\mathrm{PPE}_{\mathrm{it}}}{\mathrm{TA}_{1, t-1}}\right) \ldots
$$

Where; $\mathrm{DCA}_{\mid t}$ the discretionary accruals, proxy of the earnings management, for company $i$ at time t, $\stackrel{A}{a s}$ and ${ }_{\beta_{2}}^{A}$ are the estimations for the linear regression model. 


\subsubsection{Explanatory variables (Ownership structure)}

- Equity concentration (EC): is defined as the concentration of the company's shares and will be expressed as the percentage of the major investors of the company (those who own more than 5\% of the company's shares). Zeskhauser and Pound (1990) investigated the impact of the major investors on the financing decision of the company. They have concluded that there is no significant effect of the major investors on the capital structure of the company and that there is a significant role for the major investors in the monitoring the management for the benefit of the other investors which can reduce the ability of the management to practice earnings management. Large shareholders have more prominent motivators to monitor management, on the grounds that the expenses connected with monitor management are less than the expected benefits due to their great equity assets in the firm. Ramsey and Blair (1993) propose that increased equity concentration delivers large shareholders with necessary incentives to screen managers.

- $\quad$ Management ownership (MO): can be defined as the percentage of shares owned by the management. Previous studies have shown a significant relation between the Management ownership and earnings management. Warfield et al. (1995) have concluded that there is an inverse relation between the Management ownership and earnings management because as the Management ownership percentage increases the management interest and the individual investors' interest become more and more coincide. This will lead the management to depend more on long term investments and to thus reduce the need for earnings management practices.

- Institutional investor equity (IIE): Institutional investors play a significant role in reducing the agency cost as they monitor the performance of the management to make sure that their interests are maintained when the decisions are taken. Various studies (Jensen (1986), Shleifer and Vishny (1997), and Pound (1988)) concluded that the institutional investors played a major role in monitoring the performance of the managers. Shome and Singh (1995) have concluded that the institutional investors are forced to play a major role in monitoring the performance of the managers due to the responsibility that the institutional investors feel toward the individual investors and also to protect their own investments.

\subsubsection{Control variables}

Depending on previous studies three control variables that have impact on the ability of practicing earning management will be used in this study. Those variables are:

1. Firm's size (SIZ): the firm's size will be defined as the logarithm for the total assets. Kim et al., (2003) have concluded that firm's size effect on practicing earnings management differs among the companies. While the small firms are more attracted to practice earnings management to avoid losses disclosure, the large companies are more aggressive in practicing earnings management to maintain constant level of profit or to avoid losses disclosure.

2. The financial leverage $(L E V)$ : the financial leverage will be expressed as the debt ratio that can be calculated as the ratio of the total liabilities to the total assets. The debt ratio measures the ability of the firm to fulfill its financial obligations toward others. As the debt 
percentage increases the ability of the firm to fulfill its financial obligations decreases. Defond and Jiambalvo (1994) have concluded that as the firm reaches the situation where it cannot fulfill its financial obligations, the earnings management practices increase to enhance the image of the company. Duke and Hunt (1990) have concluded that there is a direct and significant relation between the debt ratio and earnings management practicing.

3. Profitability: it can be expressed as the Returns on Assets (ROA), which can be calculated as the ratio of the net profit before interest, tax, and extra ordinaries to the Total assets. McNichols (2000) concluded that including profitability variable in the multi regression models that determine the determinants of the earnings management will enhance the explanation power of the model.

\subsection{The model}

Based on the foregoing, the ability of the company to practice earnings management can be seen as a function in its equity concentration, management ownership's percentage, firm's size, Profitability, and Institutional investor equity as follows:

$$
\begin{aligned}
D C A_{i t}=a & +\beta_{1} E C_{i t}+\beta_{2} M O_{i t}+\beta_{3} H E E_{i t}+\beta_{4} S I Z_{i t}+\beta_{5} L E V_{i t}+\beta_{6} R O A_{i t} \\
& +\mathrm{s}_{i t}
\end{aligned}
$$

Where $D C A_{i t}$ the discretionary accruals, proxy of the earnings management, for $i^{\text {th }}$ cross-sectional firm on the $t^{t h}$ time period, with $\mathrm{i}=1,2,3, \ldots, 77, \mathrm{t}=1,2,3, \ldots, 15, \alpha$ is constant, $\beta^{s}$ are unknown parameters to be estimated, $E C$ is the equity concentration, IIE is the institutional investors; $M Q$ is the managerial ownership; $S I Z$ is the firm's sizes; $L E V$ is the leverage ratio, $R O A$ is the profitability measure, and $\varepsilon$ is the error.

\section{Results}

Table 1 shows the results of the unbalanced panel data regression analysis models we used to achieve our objective.

As expected, the results appear in Table 1 that equity concentration (EC) does have an inverse statistically significant impact on the earnings management at a statistically significant level less than 0.1 (Coeff. $=\quad-0.093$, p-value $=0.098)$. 
Table 1. Results of the unbalanced panel data regression analysis

\begin{tabular}{|c|c|c|c|c|}
\hline \multicolumn{2}{|l|}{ Variables } & Coeff. & t-value & Sig \\
\hline \multicolumn{2}{|l|}{ Constant } & 1.274 & 1.045 & 0.336 \\
\hline \multicolumn{2}{|l|}{$E C$} & -0.093 & $-1.957 *$ & 0.098 \\
\hline \multicolumn{2}{|l|}{ MO } & -0.117 & $-2.043^{*}$ & 0.087 \\
\hline \multicolumn{2}{|l|}{ IIE } & -0.193 & $-4.014 * * *$ & 0.007 \\
\hline \multicolumn{2}{|l|}{$S I Z$} & -0.082 & $-2.508 * *$ & 0.046 \\
\hline \multicolumn{2}{|l|}{$L E V$} & -0.201 & 1.907 & 0.105 \\
\hline \multicolumn{2}{|l|}{$R O A$} & 0.231 & $-3.796 * * *$ & 0.009 \\
\hline \multirow[t]{8}{*}{$d f$} & Regression & 6 & & \\
\hline & Residual & 1083 & & \\
\hline & Total & 1088 & & \\
\hline & R-Square & 31.032 & & \\
\hline & Adjusted R2 & 30.64 & & \\
\hline & F-value & 81.140 & & \\
\hline & $p$-value & 0.000 & & \\
\hline & $N$ & 1089 & & \\
\hline
\end{tabular}

Where; ***,** and* indicate significant at $1 \%, 5 \%$ and $10 \%$ respectively; EC is the Equity concentration; IIE is the Institutional investor equity; MO is the Management ownership; SIZ is the Firm's size; $L E V$ is the firm's financial leverage; ROA is the firm's Profitability; $t$ test critical value for $1 \%, 5 \%$, and $10 \%$ are $3.7074,2.4469$, and 1.943 respectively.

This result is consistent with the view that the large shareholders have the ability and the desire to monitor managers to protect their investments, managers at publicly traded firms lose their control to large shareholders and equity concentration should cut management's ability to modify accounting earnings and rise the reliability earnings. The result of this study supports the results of (Klein 2002; Kao and Chen 2004; Davidson et al. 2005 and Jaggi et al. 2007).

The results also show that there is an adversely impact at a statistical significance level less than 0.1 for the management ownership (MO) on the earnings management practices (Coeff.= $-0.117, \mathrm{p}$-value $=0.087$ ). This result is consistent with the view that lower managerial ownership has bigger motivations to practice earnings management in order to achieve their personal interests, or to mitigate the behavioral restrictions imposed in accounting-based contracts.

This result is inconsistent with the entrenchment hypothesis, which states that management ownership, instead of tumbling managerial motivation problems, may imbed the incumbent management team, leading to increasing managerial opportunism, as the entrenchment hypothesis suggests a positive association between management ownership and earnings management practices. 
As for the institutional investor equity (IIE) results came by expectation, an adversely statistically significant association between IIE and earnings management at significant level less than 0.01(Coeff. $=-0.193$, p-value $=0.007)$. This result is consistent with the Efficient Monitoring Hypothesis which suggests that institutional investors are associated with a better monitoring of management activities, dropping the ability of managers to manage earnings. This result supports the results of (Chung et al. 2002; Ebrahim 2007 and Cornett et al. 2008).

Furthermore, the results in Table 1 show that the greater the size of the company, the less the managers are motivated to practice earnings management, this result can be explained by understanding that the large-size companies are usually have more profitability, and this result confirms the inverse relationship between profitability and earnings management shown in Table 1.

\section{Conclusion}

The aim of this paper is to examine the effect of ownership structure on a firm's ability to practice earnings management. To achieve this goal all 77th Jordanian industrial companies listed at Amman Stock Exchange (ASE) for the period 2000-2014 were selected resulting in 1089 firm-year observations. The empirical results suggest that the earnings management practices of Jordanian industrial companies listed at ASE are influenced by their ownership structure. Precisely, the result shows that equity concentration, management ownership and institutional investor equity associated inversely with the practices of earnings management. Our results are consistent with the Alignment of Interest Hypothesis and the Efficient Monitoring Hypothesis which suggests that large shareholders have less motivation to manipulate earnings, and can reduce the scope of managerial opportunism.

\section{Acknowledgements}

The author is grateful to the Applied Science Private University, Amman, Jordan, for the financial support granted to this research project (Grant No. DRGS-2014-2015-210).

\section{References}

Becker, C.L., M.L. DeFond, J. Jiambalvo, \& K.R. Subramanium. (1998). The effect of audit quality on earnings management. Contemporary Accounting Research, 15, 1-24. http://dx.doi.org/10.1111/j.1911-3846.1998.tb00547.x

Blake, J. Bond, Amat, O., \& Oliveras, E. (2000). The Ethics of Creative Accounting-Some Spanish Evidence. European Review, 3, 136-142. Available at: http//web4epnet/externalframe.Asp.

Chung R., Firth M., \& Kim, J-B. (2002). Institutional monitoring and opportunistic earnings managemen. Journal of Corporate Finance, 8, 29-48. http://dx.doi.org/10.1016/S0929-1199(01)00039-6

Chung, R., M. Firth, \& J-B Kim. (2002). Institutional monitoring and opportunistic earnings management. Journal of Corporate Finance, 8, 29-48. 
http://dx.doi.org/10.1016/S0929-1199(01)00039-6

Cornett, MM, Marcus, A.J., \& Tehraniam, H. (2008). Corporate governance and pay-for-performance: The impact of earnings management. Journal of Financial Economics, 87(2), 357-375. http://dx.doi.org/10.1016/j.jfineco.2007.03.003

Davidson R., Goodwin-Stewart J., \& Kent P. (2005). Internal governance structures and earnings management, Account. Financ., pp.1-27.

DeFond, M.L., \& J. Jiambalvo. (1994). Debt covenant violation and manipulation of accruals. Journal of Accounting and Economics, 17, 145-176. http://dx.doi.org/10.1016/0165-4101(94)90008-6

Duke, J.C., \& H.G. Hunt. (1990). An empirical examination of debt covenant restrictions and accounting-related debt proxies. Journal of Accounting and Economics, 45-63. http://dx.doi.org/10.1016/0165-4101(90)90041-2

Ebrahim, A. (2007). Earnings management and board activity: An additional evidence. Review of Accounting and Finance, 6(1), 42-58. http://dx.doi.org/10.1108/14757700710725458

Farooq, O., \& El Jai, H. (2012). Ownership structure and earnings management: Evidence from the Casablanca Stock Exchange. International Research Journal of Finance and Economics, 84, 95-105.

Francis, J.R., E.L. Maydew, \& H.C. Sparks. (1999). The role of Big 6 auditors in the credible reporting of accruals. Auditing: A Journal of Practice and Theory, 18(2), 17-34. http://dx.doi.org/10.2308/aud.1999.18.2.17

Greaves, S., \& S. Waddock. (1990). Institutional ownership and control: Implications for long-term corporate strategy. Academy of Management Executive, 4, 75-83. http://dx.doi.org/10.5465/ame.1990.4274714

Jacobs, M. (1991). Short-term America: The causes and cures of our business myopia. Harvard Business School Press.

Jaggi B, \& Leung S. (2007). Impact of family dominance on monitoring of earnings management by audit committees: evidence from Hong Kong. J. Int. Account. Audit. Taxation, 16, 27-50. http://dx.doi.org/10.1016/j.intaccaudtax.2007.01.003

Jensen, Michael C. (1986). Agency Cost Of Free Cash Flow, Corporate Finance, and Takeovers. American Economic Review, 76(2). http://dx.doi.org/10.2139/ssrn.99580.

Jones, J.J. (1991). Earnings management during import relief investigations. Accounting Review, 29, 193-228. http://dx.doi.org/10.2307/2491047

Kao L, \& Chen A. (2004). The effects of board characteristics on earnings management. Corp. Ownership Control, 1(3), 96-107.

Kim, Y., Liu, C., \& Rhee, S. (2003). The Relation of Earnings Management to Firm Size, 
Available at: http://www2.hawaii.edu/ fima/Working_Papers/2003_papers/WP03-02.pdf.

Klein A. (2002). Audit committee, board of director characteristics, and earnings $\begin{array}{llll}\text { management. } \quad \text { J. Account. } & \text { Econ., } & \text { 33(3), }\end{array}$ http://dx.doi.org/10.1016/S0165-4101(02)00059-9

Klein, A. (2002). Audit committee, board of director characteristic, and earnings management. Journal of Accounting and Economics, 33, 375-400. http://dx.doi.org/10.1016/S0165-4101(02)00059-9

Lang. M.H., \& M.F. McNichols. (1998). Institutional trading and corporate earnings and returns. Stanford University Working Paper series.

Lev, B. (1988). Toward a theory of equitable and efficient accounting policy. The Accounting Review, 63, 1-21.

McNichols, M. (2000). Research design issues in earnings management studies. Journal of $\begin{array}{lllll}\text { Accounting } \quad \text { and } & \text { Public } & \text { Policy, } & 19,345 .\end{array}$ http://dx.doi.org/10.1016/S0278-4254(00)00018-1

Potter, G. (1992). Accounting earnings announcements, institutional investor concentration, and common stock returns. Journal of Accounting Research, Spring, 146-155. http://dx.doi.org/10.2307/2491097

Pound, John. (1988). Proxy contests and the efficiency of shareholder oversight. Journal of Financial Economics, 20(1-2), 237-265. http://dx.doi.org/10.1016/0304-405X(88)90046-3

Rajgopal, Shivaram, Venkatachalam, Mohan, \& Jiambalvo, James J. (March 1999). Is Institutional Ownership Associated with Earnings Management and the Extent to which Stock Prices Reflect Future Earnings?. http://dx.doi.org/10.2139/ssrn.163433.

Ramsay I, \& Blair M. (1993). Ownership Concentration, Institutional Investment and Corporate Governance: An Empirical Investigation of 100 Australian Companies. Melbourne University Law Rev., 19, 153-194.

Sanjar S., Maryam N., Nima N.; Jamal V., \& Maryam H. (2012). Earnings Management and Companies Ownership Structure in Iran (A Comparison of Earnings Management between companies with institutional investors and companies with individual investors). Journal of Basic and Applied Scientific Research, 2(2), 1728-1734.

Shiller, R.J., \& J. Pound. (1989). Survey evidence on diffusion of interest and information among investors. Journal of Economic Behavior and Organizations (August), 44-66. http://dx.doi.org/10.1016/0167-2681(89)90076-0

Shleifer, Andrei, \& Robert Vishny. (1997). The limits of arbitrage. Journal of Finance, 52, 35-55. http://dx.doi.org/10.1111/j.1540-6261.1997.tb03807.x

Shome, D., \& Sigh s. (1995). Firm Value and External Blockholdings. Financial Management, 24, 3-14. http://dx.doi.org/10.2307/3665947 
Warfield, T.D., J.J. Wild, \& W.L. Kenneth. (1995). Managerial ownership, accounting choices and informativeness of earnings. Journal of Accounting and Economics, 20, 61-91. http://dx.doi.org/10.1016/0165-4101(94)00393-J

Zeckhauser, R. J., \& J. Pound. (1990). Are large shereholders effective monitors? An investigation of Share ownership and corporate performance, in Hubbard, R.G. (ed), Asymmetric Information, Corporate Finance and Investment, University of Chicago Press. 